\title{
THE APPLICATION OF BUSINESS INTELLIGENCE SYSTEMS IN LOGISTICS. REVIEW OF SELECTED PRACTICAL EXAMPLES
}

doi: $\quad 10.2478 /$ czoto-2019-0130

Date of submission of the article to the Editor: 30/11/2018

Date of acceptance of the article by the Editor: 03/02/2019

\author{
Aleksandra Grabińska ${ }^{1}$ - orcid id: 0000-0001-7109-4305 \\ Leszek Ziora ${ }^{2}$ - orcid id: 0000-0001-9253-3952 \\ ${ }^{1,2}$ Czestochowa University of Technology, Poland, leszek.ziora@wz.pcz.pl
}

\begin{abstract}
The goal of the paper is to present the application of Business Intelligence systems belonging to the area of business analytics in the domain of logistics and particularly indicate its role and meaning in supporting logistics decision making processes. Its content embraces the characteristic of $\mathrm{BI}$ systems, its functionality, construction and benefits resulting from its implementation. The paper also presents review of research and case studies connected to the $\mathrm{BI}$ usage in such areas of logistics as optimization of supply chain, managerial dashboard design and improvement of business processes.
\end{abstract}

Keywords: Business Intelligence systems, business analytics, decision making support, logistics processes

\section{INTRODUCTION}

Nowadays many contemporary organizations apply Business Intelligence systems in its business activity, especially in the area of Logistics. The application of BI systems brings such advantages as improvement of decision making process mainly its acceleration and, allows for better functionality of particular enterprise what most of all means increased efficacy and efficiency of the whole company's functionality. The paper presents application of Business Intelligence solutions in the area of logistics and particularly in the decision making process.

\section{THE NOTION, CONSTRUCTION AND FUNCTIONALITY OF BUSINESS INTELLIGENCE SYSTESMS}

In the literature of subject many definitions of Business Intelligence systems are presented. C. Olszak and E. Ziemba claim that "from the technical perspective BI are referred to as an integrated set of tools, technologies, and software products that are used to collect heterogenic data from dispersed sources and then to integrate and analyze data to make them commonly available" (Olszak, Ziemba, 2012). P. Clavier states that " $\mathrm{BI}$ is perceived as a: technology, process, product and capability (one or multiple of these perceptions)" (Clavier, 2016). N. Kerdprasop et. al. claim that 
"Business intelligence is a broad term normally used to refer to any aspect of computer-based business applications including decision support, information management, marketing automation, and intelligent data analysis" (Kerdrasop et al., 2013). "Business Intelligence systems allow for efficient data transformation into valuable information and as its consequence enable acquisition of knowledge indispensable for making efficient decision" (Dziembek, Ziora, 2014). W. Presthus and C. Canales underline the importance of managerial dashboard in logistics company and claim that these $\mathrm{BI}$ tools should be designed properly to facilitate decision making (Presthus, Canales, 2015). As far as construction of Bl systems is concerned it is worth mentioning two approaches: the traditional one utilizing data warehouse and/or data marts and ETL processes (extraction, transformation and load of data) and the second called $\mathrm{BI}$ in memory where the use of data warehouse is not necessary. The exemplary structure of $\mathrm{BI}$ application in Logistics is depicted in Figure 1.

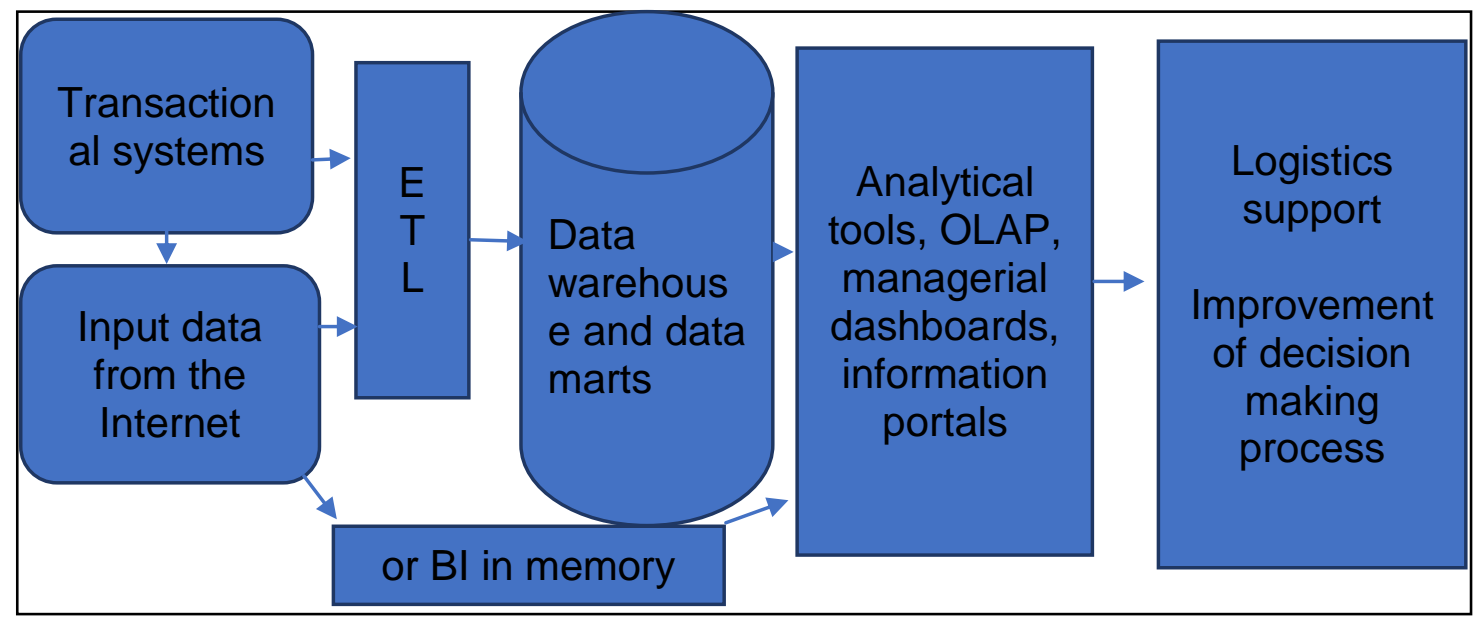

Fig 1. The construction of $\mathrm{BI}$ system supporting Logistics area

Source: Authors' study

It can be stated that "BI systems are a key feature for achievement of competitive advantage by particular company. All the modern technologies applied in contemporary enterprises such as $\mathrm{BI}$ systems, business analytics tools, data mining methods and techniques, cloud computing and big data solutions contribute to better communication within a particular enterprise, optimization and improvement of managerial processes" (Ziora, 2016). The reports generated by BI systems can be also constructed with the application of different big data methods and techniques. "Processed data may be indispensable for supporting decision making, improvement of business processes and supply chain in logistics. Big data solutions as well as $\mathrm{BI}$ systems may contribute to gaining competitive advantage of the organization which implemented it in its business activity and facilitate logistics networks creation" (Brzozowska, Sałek, Ziora ,2016). A. R. Partridge mentions that "Business intelligence/analytics is the highest-ranked functionality requested by customers, according to a recent ARC survey of leading transportation management solution vendors" (Partridge).

M. Hajdul claims that "the intensive development of Business Intelligence and Competitive Intelligence tools, access to information from multi-dimensional data 
analysis aggregated from various enterprise IT systems sources (usually in case of heterogeneous environments) has been significantly facilitated in recent years" (Hajdul, 2014).

Cerasis company which offers transportation management solutions for shippers in North America mentions such benefits resulting from application of Business Intelligence solutions as reduction of labour cost, reduction of information bottlenecks, ability to quickly prototype reports, better allocation of internal resources and ability to look at data quickly in order to help assist with decisions (Cerasis, 2017).

$\mathrm{S}$. Dowse underlines advantages of $\mathrm{BI}$ application in logistics and transportation such as: „detailed monitoring across the entire supply chain including metrics such as ontime delivery, better understanding of fuel, dray, and accessorial costs at a detail or summary level, detailed evaluation of vendor performance of on-time deliveries and work order performance, review volume of work orders by motor carrier and time between assigned and accepted to identify key partners, consolidate workload to better performing receivers, and improve equipment utilization. the ability to drill down into shipment history for decision-making and continuous improvement, visibility into events that impact on-time delivery and asset utilization for better decision-making and risk mitigation, insight into what drives costs and profit within the supply chain" (Dowse).

It is worth mentioning the fact that the implementation of particular BI system may be dependent upon the size of logistics company where bigger companies possess greater abilities in this scope and the same decision making process is different in bigger companies than in the smaller ones.

\section{THE ROLE OF BI SYSTEMS IN THE IMPROVEMENT OF LOGISTICS DECISION MAKING PROCESSES}

As far as the logistics decision processes are concerned it is worth mentioning that according to Peto in such types of decisions "higher level of uncertainty and complexity is present compared to other functional areas of an organization and he further states that for making right and effective decisions concerning logistics operations and functions, holistic and systems view is inevitable" (Peto). G. Radivojevic et al. mention the fact that "the basis for quality decision-making are the right information at the right time and the right place" (Radivojević, Šormaz, Lazić, 2013). The undertaken decisions may differ depending on the size of a company.

$P$. Hanus and K. Zowada claim that in case of small and medium sized companies "the barrier connected to appropriate decision making in the area of logistics can be insufficient time needed for data gathering, processing and its analysis. Its result may be the wrong decisions undertaken on the basis of incomplete picture" (Hanus, Zowada, 2015). It is also worth mentioning the research carried out by K. Zowada on decisions in SMEs and big companies conducted on the sample of 100 companies. The author underlines the fact that "the greater the complexity of economic processes, the greater the scope and complexity of logistic decisions" (Zowada, 2013). The cited research shows that "the size of the company determines the solutions in the field decision responsibility, including logistic decisions. The mentioned author states that "the analysis of the results indicated the following relationships: with the increase in the size of the enterprise, the importance of intuition in the logistic decision making process is decreased; with the increase in the size of the enterprise the share (the amount) of various types of analyzes (including 
commissioned analyzes), as an element supporting logistic decision making is increased, when making logistics decisions in the smallest companies decision makers most often base on experience and intuition, in other enterprises the most important elements are: experience and various types of analyses. What is more with the increase in the size of the enterprise, the share of individual character decisions is decreasing" (Zowada, 2013).

\section{PRACTICAL EXAMPLES OF BI APPLICATION IN LOGISTICS}

Business Intelligence systems have been applied in many enterprises and support many areas of enterprises' logistics business activity. Such solutions allow for conducting different types of analyses, e.g. they are widely applied in changing supply chain environment where decisions are fast-paced and needed fast, and for accurate decisions to be made, it is very important that a decision tool is able to extract and analyze data accurately (Tan, Leeb Goh, 2012). BI systems can contribute to the cost reduction in reverse logistics. S. Senthil et al. mention that "a reverse logistics defines a supply chain that is redesigned to efficient manage the flow of products or parts designed for remanufacturing, recycling or disposal and to effectively utilize resources (...) Retailers may return the goods due to seasonality, poor quality, expiry or because of transit damage. Managing the product returns increases the customer service level and retention level." (Senthil, Srirangacharyulub, Ramesh, 2012). I. Olariu mentions that companies have extended their supply chains internationally and it enables them to achieve worldwide optimization of costs (Olariu, 2014).

BI systems also support third party logistics providers which are known as $3 \mathrm{PL}$ providers and to which companies outsource logistics activities like transportation and inventory management and in this way companies avoid locking capital in warehouses trucks, containers, etc. (Srinivasa, Saurabh). Business Intelligence may support 3PL companies in: "service improvement where Business Intelligence can improve the effectiveness of services such as transportation management; warehouse and inventory management as well as value added services like light assembly and kitting analyses, cost-benefit analysis and reverse logistics by in-depth analysis and reports on various functions involved in these services. Bl can provide information technology based services by providing their clients with analysis and reports specific to their supply chain what can significantly help the customers increase their responsiveness and time to market. $\mathrm{BI}$ can improve organizational support functions like HR and financial management by providing an integrated view of these functions and supporting their specific decision making requirements" (Srinivasa, Saurabh). The authors of cited paper also mention the possibilities of $\mathrm{BI}$ application in transportation management. In these particular areas BI tools allow for carrier performance evaluation, mode-cost analysis, supplier compliance analysis, carrier relationship management, capacity planning, cycle time analysis, routing and scheduling, root cause and claims analysis as well as truck and driver performance analysis. In case of warehouse management $\mathrm{BI}$ solutions allow for inventory analysis, warehouse performance analysis, picking analysis, assigning warehouse costs and warehouse space utilization analysis (Srinivasa, Saurabh). In the area of transportation planning and management $\mathrm{BI}$ tools "can help gain insight into the complex process of transportation management and enable carrier performance evaluation, mode-cost analysis, supplier compliance analysis, carrier relationship management, capacity 
planning, cycle time analysis, routing and scheduling, truck and driver performance analysis and root cause and claim analysis" (Nwaubani).

In the supply chain $\mathrm{BI}$ can bring multiple advantages such as: achieving a costeffective means of transport; reducing transportation costs, increasing efficiencies, and improving customer service with route optimization; analyzing transport operations; cargo load optimization; managing inventory and orders efficiently and effectively; recognizing trends and understanding how they affect the business; implementing dashboards and scoreboards so that executives and supervisors can quickly recognize operational exceptions or key performance indicators (KPI); aligning daily operations with strategic objectives; analyzing transportation means to verify cost-effectiveness; making independent analyses of marketplace transportation costs (Vatovec Krmac 2011). Sahay notices that "enhancing effectiveness and efficiency of supply chain analytics using a $\mathrm{BI}$ approach is a critical component in a company's ability to achieve its competitive advantage" (Sahay 2013). The significant area of BI systems application in Logistics is optimization of logistics activities including transportation and distribution. Its applications allow for e.g. distribution costs decrease and utilization of advanced data mining techniques helps to indicate the best available solution for complex optimization problems (Olszak, Ziemba, 2006).

Business Intelligence can be combined with RFID technology for supply chain optimization. $\mathrm{H}$. Baars et al. claim that "automatic identification systems based on the Radio Frequency ID technology (RFID) are expected to become an enabler for substantial improvements in cost efficiency within transportation and warehousing processes" (Baars et al., 2008).

\section{METHODOLOGY, DISCUSSION AND REVIEW OF RESEARCH AND CASE STUDIES IN THE AREA OF BI APPLICATION IN LOGISTICS}

The opinion survey conducted on the research sample of 50 respondents - students of Logistics of Czestochowa University of Technology indicated that Business Intelligence systems bring such benefits for the companies which implemented this solution as: improvement of decision making processes (including logistics processes), shortening the time of analyses and acceleration of decision making, facilitation of different reports creation, provision of up-to-date data, data consolidation, the possibility to apply data visualization techniques, lowering functionality costs, better realization of business objectives, diversification of data sources. These results are convergent with the case studies and practical examples reviewed in the literature of subject.

The case study of $\mathrm{BI}$ adoption in retail chain was presented by $\mathrm{C}$. Olexova. The author of mentioned paper enlists benefits resulting from implementation of $\mathrm{BI}$ in the retail chain on the basis of conducted interviews among such employees as chief commercial officer, senior category managers, supply chain manager, marketing and e-commerce manager. The mentioned benefits include: "acquiring up-to-date and better quality information for decision making, improved decision making (faster, better, based on better quality information), acquiring up-to date and better quality information for decision-making, stock management optimization, improved ability to anticipate earlier changes on the market and better pricing in case of e-commerce" (Olexova, 2014). The author also mentioned that "successful adoption of $\mathrm{BI}$ in the company enhanced the value of management in the company and helped to improve business processes" (Olexova, 2014). 
Another worth mentioning case study is the one by W. Presthus and C. Canales which is connected to Business Intelligence dashboard design in WWL logistics company. It is a large company which "delivers global shipping and logistics solutions for manufacturers of cars, trucks, heavy equipment and specialized cargo and with 6000 employees worldwide" (Presthus, Canales, 2015). The authors state that in order to "improve strategic supplier related and process areas, the Global Procurement department in WWL established, in 2012, seven Key Performance Indicators - each with its related improvement target" (Presthus, Canales, 2015). The layout for performance measurement was called Rolling Performance Dashboard where „a scorecard was integrated at the centre of the dashboard in order to measure progress in each KPI and overall performance" (Presthus, Canales, 2015). The application of such a solution allowed for payment terms improvements as well as improvements in forthcoming procurement processes. The company also introduced drill-down capabilities and cross-visual interactivity by means of development and implementation of $\mathrm{BI}$ reports with advanced tools and multidimensional data modeling" (Presthus, Canales, 2015).

The other case study presenting the application of Business Intelligence in supply chain is "CF Industries" which is the second largest nitrogen producer in the world. This company "needed deep expertise with logistics and supply chain to support their current legacy system while their entire system of ledgers, receivables and more were migrated over to SAP (Globonix, 2017)" As a provider of BI solution was selected Globonix "to execute on multiple concurrent system integration requirements by delivering trustworthy experts with depth in supply chain and logistics experience and as a result CF Industries saved millions of dollars by having an effective working system in place on time and thanks to the experts it could leverage emerging best practices to efficiently use software to cut waste (Globonix, 2017)". Another company which is "a manufacturer of computer hard disk drives uses $\mathrm{BI}$ to better manage its inventory, supply chains, product lifecycles and customer relationships and it enabled the company to reduce operating costs by 50\%" (Williams, 2007). These selected case studies show the possibilities of wide application of $\mathrm{BI}$ systems in the domain of logistics.

\section{CONCLUSION}

The application of $\mathrm{BI}$ systems in the field of logistics brings such benefits for the company as improvement of the whole decision making process which is related to logistics in the areas of supply chain. The other benefits include improvement of performance in different areas of business activity. What is more such solutions allow for cost reduction and optimization in reverse logistics, support third party logistic providers, improve efficacy of transportation e.g. routes optimization as well as inventory management. Additionally, the analytics solutions by providing better quality of information for the purpose of decision making can improve the whole decision making process in logistics area as well as in the whole enterprise.

\section{REFERENCES}

Baars, H., Kemper, H.G., Lasi, H., Siegel, M. 2008. Combining RFID Technology and Business Intelligence for Supply Chain Optimization - Scenarios for Retail Logistics. In: Proceedings of the 41st Hawaii International Conference on System Sciences -2008. 
Brzozowska, A., Sałek, A., Sałek, R., Ziora, L. 2016. The Possibilities of Big Data Solutions Application in Logistics. In: XXX. microCAD International Multidisciplinary Scientific Conference University of Miskolc, Miskolc, Hungary 2016.

Cerasis: The Most Impactful Supply Chain \& Logistics Trends in 2017. https://cerasis. com/wp-content/uploads/2017/02/The-Most-Impactful-Supply-Chain_Logistics-Tre nds-in-2017-eBook.pdf.

Clavier, P. 2016. Understanding Business Intelligence Understanding: Through Goods- and Service-Dominant Logic Lenses. The Electronic Journal of Knowledge Management, 14, 2, 103-115, (available online at www.ejkm.com).

Dowse, S. Why Supply Chains Need Business Intelligence: http://www.predictive analyticsworld.com/patimes/why-supply-chains-need-business-intelligence/2600. (Retrieved 12.09.2018).

Dziembek, D., Ziora, L. 2014. Business intelligence systems in the SaaS model as a tool supporting knowledge acquisition in the virtual organization. Online Journal of Applied Knowledge Management, 2, 2, 82-96.

Globonix Case Study: CF Industries - Supply Chain BI, http://globonix.com/home/case-study-cf-industries-supply-chain/, (Retrieved 15.11.2018).

Hajdul, M. 2014. Virtual co-opetition in transport - T-Scale platform case study. Procedia - Social and Behavioral Sciences. 111, 761 - 769.

Hanus, P., Zowada, K. 2015. Narzędzia IT w logistycznych procesach decyzyjnych małych $i$ średnich przedsiębiorstw. In: Witkowski, J., Skowrońska, A. Prace Naukowe UE Wrocław, 382, Ed. UE Wrocław, 290-304.

Kerdprasop, N., Kongchai, P., Kerdprasop, K. .2013. Constraint Mining in Business Intelligence: A Case Study of Customer Churn Prediction. International Journal of Multimedia and Ubiquitous Engineering, 8, 3.

Nwaubani, J. Business Intelligence and Logistics. In: Proceedings of the $1^{\text {st }}$ Olympus International Conference on Supply Chains, Katerini, Greece, www.teicm.gr.

Olariu I., (2014) Decision making strategies regarding logistics organization, Studies and Scientific Researches. Economics Edition, No 19, 2014, (available online at http://sceco.ub.ro).

Olexova C. (2014), Business intelligence adoption: a case study in the retail chain. WSEAS Transactions on Business and Economics. Volume 11, 2014, E-ISSN: 2224-2899.

Olszak, C., Ziemba, E. 2006. Business Intelligence Systems in the Holistic Infrastructure Development Supporting Decision-Making in Organisations. Interdisciplinary Journal of Information, Knowledge, and Management, 1, (available online at http://ijikm.org/Volume1/IJIKMv1p047-058Olszak19.pdf).

Olszak, C., Ziemba, E. 2012. Critical Success Factors for Implementing Business Intelligence Systems in Small and Medium Enterprises on the Example of Upper Silesia, Poland. Interdisciplinary Journal of Information, Knowledge, and Management, 7, (available online at http://www.ijikm.org/Volume7//JIKMv7p129150Olszak634.pdf).

Partridge, A.R. Business Intelligence in the Supply Chain. http://www.inboundlogistics. com/cms/article/business-intelligence-in-the-supply-chain/ (Retrieved 11.10.2017).

Peto, M., The Decision Making Systems Model for Logistics. http://www.pefka.men delu.cz/predmety/simul/PEFnet13/prispevky/Peto.pdf (Retrieved 11.10.2017). 
Presthus, W., Canales, C. 2015. Business Intelligence Dashboard Design. A case study of a large Logistics company. (available online at http://ojs.bibsys.no/index.php/

Nokobit/article/view/261/225).

Radivojević, G.M., Šormaz, G.R., Lazić, B.S. 2013. BI applications in Logistics. In: 1st Logistics International Conference Belgrade, Serbia, 28 - 30 November.

Sahay, B.S, Ranjan, J. 2008. Real time business intelligence in supply chain analytics. Information Management \& Computer Security, 16 1, 28-48.

Senthil, S, Srirangacharyulub, B., Ramesh, A. 2012. A decision making methodology for the selection of reverse logistics operating channels. In: International Conference on Modeling, Optimization and Computing. Procedia Engineering, 38, $418-428$.

Srinivasa, R.P., Saurabh, S. Business Intelligence and Logistics, White paper. (available online at www.wipro.co.in).

Tan P.S., Leeb S. S. G., Goh A.E.S, 2012. Multi-criteria decision techniques for context-aware B2B collaboration in supply chains. Decision Support Systems. 52, 779-789, (available online at www.elsevier.com/locate/dss).

Transportation Busines Intelligence: http://cerasis.com/transportation-technology/trans portation-business-intelligence/, (Retrieved 15.11.2017).

Williams, S., Williams, N. 2007. The Profit Impact of Business Intelligence. Morgan Kaufman, Elsevier, New York.

Vatovec Krmac, E. 2011. Intelligent Value Chain Networks: Business Intelligence and Other ICT Tools and Technologies in Supply/Demand Chains decisions, (available online at www.intechopen.com), DOI: 10.5772/18850.

Ziora, L. 2016. The Applicability of Business Intelligence Systems in the Support of Managerial Decisions in the International Enterprises. International Journal of Economics and Statistics, 4, 131-135.

Zowada, K. 2013. Decyzje logistyczne w sektorze MSP - wyniki badań. Logistyka, 5, 229-231. 